\title{
DICTIONARY UPDATED WITH TERMS RELATED TO THE LOCAL POLICE F. Mateaş
}

\section{Florian Mateaş}

Law and Economics Faculty, Social Sciences Department

Agora University of Oradea, Oradea, Romania

*Correspondence: Florian Mateaş, Agora University of Oradea, 8 Piaţa Tineretului St., Oradea, Romania

E-mail: departament@univagora.ro

\begin{abstract}
The Local Police, who are a body in the service of society, not a "force" used in society, fulfill according to the European Code of Police Ethics three main tasks: first, to ensure compliance with the laws, secondly, to help people who are in danger or trouble and, thirdly, to help people in their relationship with other institutions or individuals.

We have defined the significant terms and concepts that we used throughout the paper. Secondly, we have presented the theoretical framework by using the analytical method, while also detecting the relevant items in the construction of the terms, and we have illustrated and shown the practical, applicable side of the core topics being analyzed, managing to provide a number of applications of the theoretical aspects, which bring forth the pragmatic finality of the latter.
\end{abstract}

Keywords: ensuring public order, good public management, improving citizen safety, maintaining public order, preventive notification, public order, local police officer, public servant, public safety, summons, contravention, restoring public order

\section{Introduction}

Local police agents operate in areas of public safety established at police station level through Public Order and Safety Plans, they report new developments in the operational situation, the number of inhabitants, environments and places with a risk of contraventions and criminal offences, the available manpower and means, knowledge of persons prone to commit crimes and also supplement the surveillance of those who are under the attention of police.

The action priorities set by the Public Order and Safety Plan are the main directions for focusing the efforts of the structures with responsibilities and authority in the field of public order and they are based on the following strategic objectives:

\section{Ensuring Public Order}

Ensuring public order involves "a set of specific measures, activities and actions adopted and carried out by specialized bodies of state administration, in view of the enforcement of the rules of civic conduct laid down in laws and other normative acts, of the rights and freedoms of citizens, as well as the protection of public and private property"1.

Ensuring a climate of civic normalcy, of public order and safety has always been a priority for law enforcement and public safety bodies, which, through their specialized structures have sought to identify the most effective forms and methods of achieving this goal.

\footnotetext{
${ }^{1}$ Decision No. 1040 of the $13^{\text {th }}$ October 2010 through the approval of the National Security Strategy 2010-2013 published in the Official journal No. 721 of $28^{\text {th }}$ October 2010 , index of terms p. 27
} 


\section{F. Mateaş}

Public order is enforced in accordance with the plans for public safety maintenance drafted at the level of each community police unit and sub-unit, by using the order formations in their area of competence, the formations usually consisting of patrols. following:

The national system of public order enforcement is an assembly comprising the

- legislation;

- the forces of public order;

- training;

- leadership.

In conclusion, ensuring public order means imposing law enforcement measures, in order to prevent and deter acts aimed at causing social disturbances or violence during public gatherings and demonstrations, cultural and sports activities, as well as other similar events with large attendance. The measure of ensuring public order and safety is among the duties of the Local Police and of the Romanian Gendarmerie, which, according to Law No. 550 of $29^{\text {th }}$ November 2004 on the organization and functioning of the Romanian Gendarmerie, Chapter 3, Article 19, paragraph 1, letter b, "perform the tasks of ensuring public order during meetings, marches, demonstrations, processions, picketing actions, promotional, commercial, cultural and artistic, sports, religious, commemorative events, and other such activities taking place in the public space and involving crowds of people" and, according to Law No. 155 of $12^{\text {th }}$ July 2010 on the Local Police, Chapter III, Article 6, letter g: they "participate, together with other relevant authorities to ensuring public order and tranquility during meetings, marches, demonstrations, processions, picketing actions, commercial, promotional actions, cultural and artistic, sports, religious or commemorative events, as appropriate, as well as other such activities taking place in the public space and involving crowds of people".

Good Public Management - expresses the way of arranging things orderly, the manner in which an action, an established or imposed system of organization goes on.

\section{Improving the Safety of Citizens}

Public or citizen safety measures consist of all preventive legal actions that public institutions take in order to increase the safety level of individuals, communities and goods.

The main objectives for improving citizen safety are:

- street safety

- safety on public transport.

- road traffic safety.

The main general objectives arising from the public order and safety plan:

1. Improving the legislative framework, particularly in the field of public order, with regard to the implementation and enforcement of contravention measures.

2. Allocating resources within the public order and safety system, in order to cover the street and strengthen local police structures.

3. Strengthening the operational situation management, by:

- Carrying out public order maintenance activities in an integrated system, in order to reduce antisocial acts on means of transport, as well.

- Structuring the manner of organization of the public order forces, in order to ensure patrolling and intervention if necessary.

- Collecting data and information on the incidents, events and tasks to which the resources for maintaining, ensuring and restoring public order are allocated.

- Extending the tactical analysis system for monitoring and evaluating the operational situation, as well as planning the public order maintenance activities;

- Ensuring a climate of normalcy during the performance of activities with large attendance. 
DICTIONARY UPDATED WITH TERMS RELATED TO THE LOCAL POLICE

4. Increasing efficiency in the field, by enforcing and checking specific measures in certain key situations.

5. Promoting a behaviour that enhances public safety in the community, through the local police officers, in order to increase awareness and the identification of threats on the local community.

6. Developing action procedures applicable to all police officers. institutions.

7. Ensuring a climate of public safety and order in pre-university educational

8. Improving the quality of public service in the field of public order.

It is one of the most important services, given its direct impact on citizens through: services;

- The increase of transparency and impartiality in the delivery of public police

- The correct, concise and timely information of citizens with regard to the activities performed by police officers;

- The improvement of the service handling requests, petitions and notifications;

- The improvement of the work with citizens.

\section{Public Tranquility}

Public tranquility means "the usual, constant climate of understanding, peaceful coexistence of life in society"2.

Public tranquility is disturbed when "this peaceful environment is removed and replaced by a state of general excitement, in which the sense of personal security is affected by fear and anxiety, in which understanding and peaceful coexistence are replaced by states of conflict, in which the healthy atmosphere that should characterize life in society is flawed"3.

In conclusion, public tranquility is the result of compliance with all rules of conduct established either by law or by the common sense of all people, so that each of us may live in harmony with all others.

\section{Maintaining Public Order}

Maintaining public order involves "all measures, activities and actions organized and carried out daily by law enforcement and public safety bodies, for the normal functioning of state institutions, the protection and respect of citizens' fundamental rights, the norms of civic conduct, rules of social coexistence, the other supreme values, as well as public and private property"4.

Public order maintenance is based on the following issues arising from the principle of professionalism:

1. The capacity for information which is necessary for the development of technical and criminological situations that will allow the formulation of real predictions and the improvement of the database held by institutions with regard to objectors, the means available to them, their operating modes, as well as the area in which they operate or can operate. The

\footnotetext{
${ }^{2}$ Romanți Liviu-Marian, Teorie şi practica aplicativă în legislaţia contravențională - partea specială (Theory and Applied Practice in Contravention Law - the Special Part), Ed. Eurodidact (Publishing House),ClujNapoca, 2012, p.15

${ }^{3}$ Darius Stănculescu, Mirel Roman, Mihai Marin,Cătălin-George Spînu, Note de curs, Legislație contravențională (Lecture Notes, Contravention Legislation), vol. II, The Special Part, Ed. C. H. Beck (Publishing House),Bucharest, 2009, p. 3

${ }^{4}$ Ministry of Administration and the Interior, General Directorate for the Organization and Planning of Missions and Resources - Coordinator: Chief Commissioner Adrian Romanică, Glosar de termeni din domeniul ordinii şi siguranţei publice (Glossary of Terms in the Field of Public Order and Safety), Ed. Ministerului Administraţiei şi Internelor (Publishing House of the Ministry of Administration and the Interior), Bucharest, 2006, p.169
} 


\section{F. Mateaş}

establishment of a database will allow the anticipation of future protest actions and the rationalization of police intervention.

2. Speed of reaction when the acts of disturbers are outside the authorized range is required so that the public order maintenance formations may be organized and deployed to intervene in the shortest time limit possible. Most times, this allows the control of this allows the control of the situation and the avoidance of the chain incitement to public disorder.

3. The force of reaction takes into consideration the fact that the forces disturbing public order are becoming more and more violent and that they often resort to the use of weapons and dangerous equipment, and police forces must be able to react for their deterrence, scattering or, if needed, neutralization by force, as allowed by their logistics.

4. The control of the situation in time and space considers the fact that large-scale social protest actions may manifest over long periods of time and extend over large areas. These situations impose the need for the state to be able to employ authorized public intervention force which should be endowed with the appropriate tactics and equipment allowing an efficient and quick reaction.

5. The management of the control activity requires that the operations for ensuring and restoring public order should be organized and executed according to the established intervention plan, improvisation, inappropriateness and poor preparation being doomed to fail.

In conclusion, public order maintenance is part of the public order and safety structure which is accountable for the needs and safety of the community, through the development and implementation of operational programmes and strategies appropriate to the operational situation existing in a certain stage of social development.

The measure of maintaining public order and safety is among the duties of the Local Police and the Romanian Police according to Law No. 218 of $23^{\text {rd }}$ April 2002 on the organization and functioning of the Romanian Police, Chapter III, Art. 26, para. 1, point 2: "[they] enforce measures for maintaining public order and tranquility, the safety of citizens, for preventing and combating crime and identifying and counteracting the actions of agents that pose a threat to the life, freedom, health and integrity of individuals, private and public property and other legitimate interests of the community" and, according to Law No. 155 of $12^{\text {th }}$ July 2010 on the Local Police, Chapter III, Art. 6, letters a and b, "[they] maintain public order and tranquility in areas and places established through the Public Order and Safety Plan of the unit/administrative-territorial subdivision approved according to the law" and "[they] maintain public order in the vicinity of public schools, public health establishments, in car parks located on the public or private space of the unit/administrative-territorial subdivision, in commercial and recreational areas, parks, markets, cemeteries, as well as other such public places owned and/or managed by the units/territorial-administrative subdivisions or other institutions/local public services established through the Public Order and Safety Plan”.

4. Preventive Notification - is "the action of notifying the authorities or the population, by official notice, of a situation or decision for a prophylactic, preventive or averting purpose"

Preventive notification contains personal data which are divided into two categories depending on their origin:

\footnotetext{
${ }^{5}$ Ministry of Administration and the Interior, General Directorate for the Organization and Planning of Missions and Resources - Coordinator: Chief Commissioner Adrian Romanică, Glosar de termeni din domeniul ordinii şi siguranţei publice (Glossary of Terms in the Field of Public Order and Safety), Ed. Ministerului Administraţiei şi Internelor (Publishing House of the Ministry of Administration and the Interior), Bucharest, 2006, p.180
} 
DICTIONARY UPDATED WITH TERMS RELATED TO THE LOCAL POLICE

1. When the personal data are obtained directly from the data subject, unless that person already holds the respective information, the controller is obliged to provide at least the following information:

a) the identity of the controller and of his representative, if any;

b) the purpose of the data processing;

c) additional information, such as: the recipients or categories of recipients of the data; whether the supply of the requested information is mandatory and the consequences of the refusal to provide it; the existence of legal rights, especially the right to access, to intervention on the data and of opposition, as well as the conditions for their exercise;

d) any other information which is requested by order of the supervisory authority, taking account the specific nature of the processing.

2. When the data are not obtained directly from the data subject:

Except when the data subject already has the respective information, the controller is obliged to provide the data subject with at least the following information at the time of data collection or, if a disclosure to third parties is envisaged, no later than the time when the data are first disclosed:

a) the identity of the controller and of his representative, if any;

b) the purpose of the data processing;

c) additional information, such as: the categories of data concerned, the recipients or categories of recipients of the data, the existence of legal rights, especially the right to access, of intervention on the data and of opposition, as well as the conditions in which they may be exercised;

d) any other information which is requested by order of the supervisory authority, taking account the specific nature of the processing.

\section{Public Order}

The notion of public order was first established in the Romanian Constitution in Art. 53 point 1: "The exercise of certain rights or freedoms may be restricted only by law and only if necessary, as appropriate, for: the defence of national security, of public order, health or morals, of the rights and freedoms of citizens; conducting a preliminary criminal investigation; preventing the consequences of a natural calamity, of a disaster, or an extremely serious catastrophe". This term has also been used in the Declaration of Human Rights, Art. 29, point 2: "In the exercise of his rights and freedoms, everyone shall be subject only to such limitations as are determined by law solely for the purpose of securing due recognition and respect for the rights and freedoms of others and of meeting the just requirements of morality, public order and the general welfare in a democratic society".

Public order represents the desire of the overwhelming majority of the population in need of having their life, health, property and, last but not least, the possibility to freely express their options, protected.

According to the definition, the concept of "public order" includes activities that regard: the citizen's relationships with other members of society concerning the use of a public good, the supply of a public service, his relationships with others in order to achieve those rights and freedoms which by their nature involve a collective activity, often performed in public places, public health and hygiene, public violence limitation, ensuring the peaceful nature of public demonstrations, as well as the prohibition of certain activities.

In terms of content, public order is a synthesis of its components:

- natural order, which represents the state of equilibrium of natural and environmental factors;

- social order, which represents the peaceful coexistence and cooperation between members of society, without violating their rights and interests.

- rule of law, which represents the normal functioning of law authorities, created to ensure compliance with the law. 


\section{F. Mateaş}

The concept of "public order" may be analyzed from several points of view:

- In the field of juridical sciences, public order is "a state of law and fact which allows achieving and maintaining an equilibrium based on the social consensus required for an optimal functioning of the social system as a whole in the conditions of the internal legal regulations in force, the consecration, protection and respect of the fundamental rights and freedoms of citizens, public and private property, the other supreme values in order to promote and assert social progress in a democratic society".

- In the field of administrative sciences, public order is defined by:

- Its prominent material character, "in the sense of action meant to avoid visible disturbances";

- Its public character, "in the sense that the police do not only comply with internal regulations, but also respect the private domain, to the extent to which the activities carried out have an effect on the outside world".

- Its limited character, "in the sense that it relates to three aspects: tranquility (keeping order in the streets, in public places, the fight against noise), security (in the sense of safety in case of human or natural accidents, fire, floods, armed conflicts), sanitation (defending public hygiene)"7.

In conclusion, we may say that "public order" is a state of equilibrium and tranquility that ensures a climate of civic normalcy, in compliance with legal rules and norms of civic conduct, allowing the exercise of constitutional rights and freedoms.

\section{The Local Police Officer, as Public Servant}

The term "police officers" is not understood by everyone in the same way, which is why a need was felt to set the boundaries of its meaning in several international or regional regulations. Thus, the Police Code of Conduct, which is included in the Annex to the UN General Assembly Resolution regarding the coordinates of conduct of law enforcement officials, in the comments to Art. 1, shows that this term includes all officers of law, whether appointed or elected, who exercise police powers, especially the powers of arrest and detention and, in countries where police powers are exercised by military authorities, whether uniformed or not, or by state security forces, the definition of "police officer" shall be regarded as including officers of such services ${ }^{8}$.

The local police officer is a public servant having the competence to enforce law at local, county or national level. The rules laid down in the Statute of Public Servants apply to the public servants of the Local Police, whereas labour law regulations apply to the contractual staff.

A public servant "is a person appointed to public office. Public office represents all duties and responsibilities established by the public authority or institution, under the law, in order to achieve its powers" ". Public office means "a complex set of powers, duties, responsibilities and attributions set out within a public service in order to satisfy continuously and rhythmically the general interests of society" 10 .

In the doctrine and the jurisprudence, the concept of public servant has been addressed by different branches of law as having several meanings:

\footnotetext{
${ }^{6}$ Drăghici Ion, Conceptul de ordine publică şi reflectarea lui în legislația actuală (The Concept of Public Order and Its Reflection in the Current Legislation),Bucharest, 2007, p. 2

${ }^{7}$ Verginia Vedinaş, Drept administrativ, Ediţia a V-a revăzută şi adăugită (Administrative Law. Fifth Edition Revised and Enlarged), Ed. Universul Juridic (Publishing House), Bucharest, 2009, p. 11

${ }^{8}$ Code of Conduct for Law Enforcement Officials, adopted by Resolution no. 34/69 of $17^{\text {th }}$ December 1979 of the UN General Assembly

${ }^{9}$ Law No. 188/1999 on the Statute of Public Servants, Chapter I, Art. 2, points 1-2.

${ }^{10} \mathrm{P}$. Negulescu,Tratat de drept internaţional (Treatise of International Law), $4^{\text {th }}$ edition, Editura Mârvan (Publishing House), Bucharest, 1934, p.531
} 
- In the Romanian criminal law, a public servant is any person who exercises, permanently or temporarily, in any form, no matter how he/she was invested, a task of any kind, remunerated or not, in the service of a unit.

- In the administrative law, a public servant is the individual who holds a state office or is vested with a certain state office, held legally.

In conclusion, the local police officer is a public servant with a specific status operating "in the interest of the local community, solely on the basis of and in order to enforce law, as well as the acts of the deliberative authority and the executive one of the local public administration, and also in accordance with the specific regulations of each activity field, set by administrative documents of the local and central public administration authorities"11.

\section{Public Safety (Public Security)}

The meaning of the term "public safety" is "to express the sense of tranquility and trust that the security and protection service gives rise to by enforcing the measures aimed at maintaining public order and tranquility, the safety of persons, communities and goods, as well as achieving the partnership civil society - order bodies in order to address community issues, the defence of the rights, freedoms and legal interests of citizens" $" 12$.

The state of public order and safety is achieved by general economic, social and political measures, as well as special measures, mainly of a preventive nature. With all these measures, we are witnessing a "maintenance of the vulnerability of citizen safety, a perpetuation of crime and development of organized crime, although the capacity of state institutions to respond to specific risks and threats has increased"13.

If examined from the point of view of police practice, the duties in the field of public safety may be grouped into the following categories:

- The protection of state security, the state being the supreme organization form of the community. Taking into account the prevailing importance of state security protection, the national security legislation grants major powers to a special branch of the police, having the special mission of watching over the security of the state. From an organizational point of view, the framework of these powers naturally includes the surveillance of political and social movements, public meetings, various associations and organizations, etc...

- The protection of individual security may be divided from a practical point of view into the following groups:

a. Protection of the person delivered into the custody of the police.

b. Protection against dangers caused by natural disasters or calamities, by fire, floods, earthquakes, etc., in which case, in addition to police bodies, firefighting services and, if necessary, bodies of other competent administrative services are called to work together with the army to prevent losses and save people's lives and property.

- The protection of material goods includes real estate security against damage caused by wrongdoers or negligence, ensured concurrently by police bodies, own security force, military security, specialized security companies, civic security in communes and villages.

8. Summons is a police measure consisting of an order to execute or cease an action being carried out, in order to:

a) disrupt the beginning of committing an illegal act;

b) interrupt ongoing antisocial acts;

c) interrupt acts of disturbance of public order;

\footnotetext{
${ }^{11}$ Law No. 155 of $12^{\text {th }}$ July 2010 on the Local Police, Art. 2, point 1, letters a and b.

${ }^{12} \mathrm{http}: / / \mathrm{www}$.politiaromana.ro

${ }^{13}$ Mateaș Florian, Note de curs-Politie Locală I ((Lecture Notes - The Local Police I), Agora University, Law and Economics Faculty, year 2013
} 


\section{F. Mateaş}

d) put an end to such acts or detain suspects;

e) eliminate manifestations of resistance from individuals, as well as disarm aggressive and turbulent elements;

f) flush out people from hiding places;

g) prevent the escape, entry or withdrawal without right of persons to or from certain objectives, clearly defined perimeters" ${ }^{\prime 14}$.

The number of summons and their contents are determined by legal provisions, the number and behaviour of the individuals, as well as the deed committed, the execution stage, the time the police officer has at his disposal, and also the measure to be taken after the summons.

Tactical rules to be observed when summoning people:

a) perform the summons in a loud voice, in short words, uttered forcefully, in an authoritative tone, from a suitable distance away from the person summoned, which should guarantee your security;

b) follow the two stages of the summons:

- The first stage of the summons is preventive in nature, you ask the person to perform a certain action, while also presenting the authority on whose behalf the summons is made: “THIS IS THE POLICE! FREEZE!", "STOP! THIS IS THE POLICE!".

- The second stage consists in repeating the request to the person summoned to perform a certain action, also presenting the police officer's action in case of disobedience (“STOP OR I'LL SHOOT!”; “SCATTER! WE WILL USE...”);

c) allow a short interval of time between the stages of the summons, in order to observe the reaction of the person summoned and to leave enough time for him/her to execute your instructions, you should only make the transition to the next stage and the intervention itself only in case of disobedience;

d) constantly watch and observe the person summoned, so that you can predict his/her movements and intervene if necessary;

e) if you assume that the person summoned is carrying weapons, summon from a place where you are protected;

f) when operating at night and lighting of the suspect person or the surroundings is needed, for security purposes, the light source should be kept away from the body, so that it is not an indication of your position;

g) if the person summoned has ceased action, approach him/her with caution and proceed, as appropriate, to immobilize him/her or perform other police measures;

h) if two or more police officers take part in the action, operate in different directions: the one in charge of protection should ensure lighting from a shelter that would ensure his/her protection and the other should intervene in view of summoning and immobilizing the suspect; under no circumstances should the police officers act in opposite directions.

9. Contravention. This concept is defined as: "the act committed with guilt, established and sanctioned by law, ordinance, Government decision or, where appropriate, by decision of the local council of the commune, town, municipality or sector of Bucharest, the county council or the General Council of Bucharest Municipality".

The term "contravention" has three meanings in contravention law (two meanings are abstract and one is concrete):

- In its abstract sense, it "may be seen in relation to other forms of illegal acts or to distinguish different types of contravention illegal acts from each other"15;

\footnotetext{
${ }^{14}$ Arad Police - Coordinator: Police Chief Commissioner Ioan Roșca, Police Commissioner Pavel Hălmăgean, Manualul polițistului de ordine publică (Manual of the Public Order Police Officer), Ed. Concordia (Publishing House), Arad, 2007, p.18
} 
- In its strict sense, it "is an offence provided (described) by contravention law, these rules are based on the assumption that the act prohibited might be committed again, being a kind of hypothetical illegal act" ${ }^{\text {"16; }}$

- In its concrete sense, contravention "is an act of a person, committed with guilt, which violates a rule that forbids it, classifying it as a contravention, defined as a behaviour taking place in the surrounding world"17.

From a legal point of view, contravention is a juridical fact, a type of inconvenient activity because it harms and jeopardizes the rights and interests of society or of individuals.

From a social point of view, contravention is an act which causes a harm to a subject of law or endangers social order.

From a natural point of view, contravention appears as a deviation of conduct of a member of society, who is disrespectful to the other constituents of the group to which he/she belongs.

From a moral perspective, contravention appears as an activity contrary to the minimum ethical conscience of society.

\section{Restoring public order}

Restoring public order involves "all legal measures, mainly repressive, based on coercion, including the use of physical force and firearms, enforced by the bodies with statutory powers to restore the situation created by a serious breach of public order, which endangers the security of the state, citizens, public and private property, to a state of normalcy" $" 18$.

Public order restoration includes a set of specific actions organized and executed in due time, depending on the situation, which is based on the use of the technical means and equipment provided, aimed at restoring the situation to a state of normalcy.

Public order restoration is based on the following principles:

- The principle of legality - the actions of the forces of public order and safety are in the spirit and in compliance with the laws and citizens, in the exercise of their constitutional rights and freedoms, are subject only to such limitations as determined by the law and natural moral requirements.

- The principle of territoriality and mobility of forces - public order and safety forces are organized at central and territorial level, with structures and powers suitable for the disposition and organization of administrative-territorial units and the development of the crime phenomenon.

- The principle of prevention of acts of public order disturbance reflects the ability of the management bodies and law enforcement forces to take in due time the necessary measures in order to avoid any acts or facts which might affect public order, to prevent their amplification and degeneration into violent acts or actions that seriously affect public order.

- The principle of operability and interoperability reflects the ability and availability of law enforcement forces to perform actions within the national space, to cooperate with similar forces from other states and perform specific tasks for maintaining peace and removing the effects of disasters, as part of international bodies, on the territory of other states.

\footnotetext{
${ }^{15}$ Mihai Adrian Hotca, Regimul juridic al contravenţiilor. Comentarii şi explicaţii. Ediţia 5 (The Legal Regime of Contraventions. Comments and Explanations. Fifth Edition), Editura C.H.Beck (Publishing House), Bucharest, 2012, p.16

${ }^{16}$ M.A.Hotca, op.cit., p.16

${ }^{17}$ M.A.Hotca, op.cit., p.17

${ }^{18}$ Ministry of Administration and the Interior, General Directorate for the Organization and Planning of Missions and Resources - Coordinator: Chief Commissioner Adrian Romanică, Glosar de termeni din domeniul ordinii şi siguranţei publice (Glossary of Terms in the Field of Public Order and Safety), Ed. Ministerului Administraţiei şi Internelor (Publishing House of the Ministry of Administration and the Interior), Bucharest, 2006, p.231
} 


\section{F. Mateaş}

- The principle of non-discrimination requires law enforcement and public safety forces to adopt a correct, impartial and non-discriminatory conduct, without distinction of race, sex, religion, nationality, political affiliation, property or social origin, towards all citizens.

- The principle of avoidance of surprise implies an obligation of the decision makers in the field of public order and safety to warn and summon with regard to the use of the equipment provided, especially firearms, and, where appropriate, grant the time necessary for the people involved to cease their actions and/or leave the area.

- The principle of sufficiency, graduality and proportionality involves the use of force proportionally with the type and degree of public order disturbance, only to the extent strictly necessary and for a limited period of time, sufficient to achieve the desired objective. The procedures and means of action involving coercive measures will be used progressively and only if absolutely necessary.

- The principle of permanent collaboration with the community. In performing their duties, law enforcement forces ground their whole activity on the wide support of citizens and act with respect for the public.

- The principle of the inviolability of the person establishes that any person has the right to respect for their life, physical and moral integrity, as well as the inseparable attributes of their personality. This principle includes the prohibition of torture or ill-treatment, as well as the person's right to a fair and correct trial, before a competent, independent and impartial law court.

- The principle of specialized intervention and cooperation. The use of the main and supporting, complementary and exceptional law enforcement and public safety forces place in maintaining and restoring public order takes place in relation to the legal powers, the training and equipment specific to each category of forces.

- The principle of unitary management, structural and relational optimization, harmonization and synchronization of actions in order to achieve the goals intended, with minimal effort and best results.

The structure of public order and safety consists of:

1. main forces;

2. supporting forces;

3. complementary forces;

4. exceptional forces.

In conclusion, the measure of restoring public order and safety is among the responsibilities of the Romanian Gendarmerie according to Law No. 550 of $29^{\text {th }}$ November 2004 on the organization and functioning of the Romanian Gendarmerie, Chapter 3, Art. 19, para. 1 letter c: "to execute missions for restoring public order when it has been disturbed by any actions or acts which contravene existing laws".

\section{References}

1. Criminal Code, Hamangiu Publishing House, Bucharest, $24^{\text {th }}$ edition, revised, updated on $20^{\text {th }}$ August 2012;

2. Criminal Procedure Code, Hamangiu Publishing House, Bucharest, $24^{\text {th }}$ edition, revised, updated on $15^{\text {th }}$ May 2014;

3. New Civil Procedure Code and 11 Common Laws, edition updated on $15^{\text {th }}$ May 2014, Hamangiu Publishing House;

4. Law No. 188/December 1999 *** Republished on the Statute of Public Servants, published in the Official Journal, Part I, no. 365 of $29^{\text {th }}$ May 2007, effective date $18^{\text {th }}$ July 2010;

5. Law No. 215/2001 on the Local Public Administration, published in the Official Journal, No. 204 of $23^{\text {rd }}$ April 2001, amended by Law 286/2006; 
DICTIONARY UPDATED WITH TERMS RELATED TO THE LOCAL POLICE

6. Law No. 7 of $18^{\text {th }}$ February $2004^{* * *}$ Republished on the Code of Conduct for Public Servants, published in the Official Journal No. 525 of $2^{\text {nd }}$ August 2007;

7. Law on the Local Police No. 155 of $12^{\text {th }}$ July 2010, published in the Official Journal No. 488 of $15^{\text {th }}$ July 2010 , effective date $1^{\text {st }}$ January 2011 ;

8. Law No. $61 / 27^{\text {th }}$ September 1991 (*republished*) sanctioning the acts of violation of rules of social coexistence, public order and tranquility, published in the Official Journal No.77 of $31^{\text {st }}$ January 2011, effective date $31^{\text {st }}$ January 2011;

9. M. Basarab, Drept penal. Partea generală (Criminal Law. The General Part), Lumina Lex Publishing House, Bucharest, 1999;

10. A. Iorgovan, Răspunderea contravenţională (Contraventional Liability), Doctoral Thesis, Bucharest, 1979;

11. V. Mirişan, Drept penal parte specială (Criminal Law. The Special Part), Lumina Lex Publishing House, Bucharest, $2^{\text {nd }}$ edition, 2008;

12. R.N. Petrescu, Drept administrativ (Administrative Law), Ed. Cordial Lex (Publishing House), Cluj Napoca, 2001;

13. R.N. Petrescu, Drept administrativ (Administrative Law), Hamangiu Publishing House, Bucharest, 2009;

14. L.R. Popoviciu, Drept penal Partea generală $\sim$ Curs universitar (Criminal Law. The General Part - University Course), PRO Universitaria Publishing House, Bucharest, 2011;

15. I. Oancea, Drept penal. Partea generală (Criminal Law. The General Part), Didactic and Pedagogic Publishing House, Bucharest, 1965;

16. M. Ursuţa, Procedura contravenţională (Contravention Procedure), Ed. a II-a (2 ${ }^{\text {nd }}$ edition), Universul Juridic Publishing House, Bucharest, 2009;

17. V. Vedinaş, Drept administrativ, Ed. a VII-a revăzută şi actualizată (Administrative Law, $7^{\text {th }}$ edition revised and updated), Universul Juridic Publishing House, Bucharest, 2012;

18. Manualul Politiei Comunitare (Community Police Manual), group of authors, coordinators: PhD Prof. Stancu Şerb, PhD Prof. Ţuţu Pişleag, Cermaprint Publishing House, 2006;

19. Introducere în teoria şi practica poliţiei comunitare (Introduction to the Theory and Practice of Community Policing), scientific coordinators: PhD Prof. Pavel Abraham, PhD Prof. Costică Voicu, PhD Assoc. Prof. Bujor Florescu, Concordia Publishing House, Arad, 2008 . 